\title{
Graeco-Roman Fertility Figurines from Gayer-Anderson Museum, Cairo ${ }^{1}$
}

\author{
By Noha ShaLABY
}

\begin{abstract}
Gayer-Anderson Museum includes a large collection of fertility figurines, most of which are not displayed. The main problem of this collection is the lack of provenance, which resulted in a difficulty of providing an accurate dating. The fertility figurines had a long tradition in Egypt. Selected for this article are six figurines dating to the Graeco-Roman period: Three Egyptian deities (Harpocrates 'on display', Bes, and Pataikos), the so-called Baubo or Hathoric Figurine that is related to both Egyptian and Greek myths, a Greek male deity (Priapus), whose cult started to be popular in Egypt in the $3^{\text {rd }}$ century BC, and Symplegma or Copulating Pair. Each figurine has certain significance and/or shows a specific role in religious rituals or festivals. Both Egyptians and Greeks were acquiring such figurines mostly for protective and apotropaic purposes.
\end{abstract}

Keywords: Graeco-Roman Egypt - fertility - Gayer-Anderson - Harpocrates Baubo - Hathoric Figurines - Bes - Priapus - Pataikos - Symplegma.

\section{Introduction}

A large and varied group of fertility figurines are kept at Gayer-Anderson Museum. Few figurines were already on display in the "Pharaonic Room" at the third floor of the older house known as Beit Amna bent Salim. The majority, however, are stored on two shelves inside a wooden closet wall at the "Reading Room" of the second floor of the other more recent house known as Beit Al-Kretliya (House of the Cretan Woman). ${ }^{2}$ The two

\footnotetext{
${ }^{1}$ I am grateful to Dr. Nevine Nizar, who drew attention to the presence of a large stored group of fertility figurines at the museum. Together with my colleague Dr. Mona M. R. ElSayed, we will be shortly publishing a catalogue for the whole collection. Thanks are also due to the extremely helpful museum staff, with a special appreciation to Mrs Safaa Hanafi.

${ }^{2}$ Beit Al-Kretliya is also known as Sabīl wa-Manzel Mohamed ben El-Hāg Sālem Al-Gazzār, see M. Ahmed, Dalīl Mougaz le-Aham Al-'Ațār Al-'Arabiya bel-Qāhera, Cairo: Al-Matba'a Al-'Amīriya be-Boulāq, 1938, p. 197-201. The museum consists of two houses connected by a bridge (one dating to the $16^{\text {th }}$ century and the other to the $17^{\text {th }}$ century); the more recent house had been owned by a Cretan woman who gave it its current name, see N. Warner, Guide to the Gayer-Anderson Museum. Cairo, Cairo, 2003, p. 5; A. ZAKI, Dor Al-Tohaf fi Misr we Al-Gam 'yät Al- 'Elmeya, Cairo, 1949, p. 40-42 (dating the older house to the $15^{\text {th }}$ century "Sultan Qaitbay's Reign"). For more details on the Interior design of the house, cf. M. M. N. AbDel Salam, Derāṣa Taḥlīliya lel-'Emāra Al-Dāhliya wa Al-Ațāt le-Beit Al-
} 
connected houses were occupied by Major R. G. Gayer-Anderson from 1935 to 1942 based on a deal made with the Comité de Conservation des Monuments de l'Art Arabe, which was free rent for life in return for handing them back to the Egyptian State with his large collections upon his death. ${ }^{3}$ In 1943, they were turned into a public museum under the supervision of the Museum of Arab Art (now Museum of Islamic Art). ${ }^{4}$

Since his arrival in Egypt in 1907, Gayer-Anderson was known of his obsession of collecting antiquities. ${ }^{5}$ He focused on purchasing the small handy artifacts, ${ }^{6}$ and occasionally worked as an antiquities dealer. ${ }^{7}$ Objects from his collections mainly made their way to British, European and United States museums, ${ }^{8}$ of which Wellcome was the only museum to purchase merely fertility themed objects, i.e. phallic figurines. ${ }^{9}$

The fertility figurines of Gayer-Anderson museum are mainly made of terracotta, yet very few were made of other materials such as faience and limestone. The main problem of the collection is the lack of provenance; however, such erotic material - usually termed as indecent figures - is likely to have come from Naucratis and its hinterlands. ${ }^{10}$ About sixty four figurines were kept hidden from the visitors' eyes for several decades, ${ }^{11}$ of which five

Kretliya wa-Ta'țīroh 'ala Al-Tașmīm Al-Dāḥli wa Al-Ațāt fi El-Modon Al-Gadīda, unpublished M.Sc. Thesis, Helwan University, Cairo, 2003.

3 R. G. GAYER-ANDERSON et al., Legends of the House of the Cretan Woman, Cairo: American University Press, 2001, p. 8; A. E. E. El-HABASHI, Athar to Monuments: The Intervention of the Comite de Conservation des Monuments de L'Art Arabe, PhD Diss., University of Pennsylvania, 2001, p. 73, n. 43.

4 'Abd Al-Raḥmān Zaki, Mawso 'at Madinat Al-Qāhīra fi Alf 'am, Cairo: Maktabat Al-Anglo Al-Masriah, 1969, p. 242-243; R. M. Mūḥammed, Madhal īlā Fan Al-Matāḥef, Cairo: AlDār Al-Mās̆rīā Allībnānnīā, 2002, p. 86.

${ }^{5}$ N. WARNER, Collecting for Eternity: R.G. Gayer-Anderson and the Egyptian Museum in Stockholm, Stockholm: National Museum of World Culture, 2016, p. 4.

${ }^{6}$ S. IKRAM, "A Pasha's Pleasures: R.G. Gayer-Anderson and his Pharaonic Collection in Cairo", in S. D'Auria (ed.), Offerings to the Discerning Eye. An Egyptological Medley in Honor of Jack A. Josephson, Leiden, 2010, p. 178.

${ }^{7}$ WARNER, Collecting for Eternity, p. 4.

${ }^{8}$ IKRAM, "A Pasha's Pleasures", p. 180.

9 J. E. GROVE, The Collection and Reception of Sexual Antiquities in the Late Nineteenth and Early Twentieth Century, unpublished PhD Thesis, University of Exeter, 2013, p. 88-89.

${ }^{10}$ This assumption is due to the large quantity of these figurines were found at the Naucratis, cf. R. ThOMAS, "Egyptian Late Period figures in terracotta and limestone", in A. Villing, M. Bergeron, G. Bourogiannis, A. Johnston, F. Leclère, A. Masson, R. Thomas et al., Naucratis: Greeks in Egypt, p. 1, Online Research Catalogue of the British Museum. http://www.britishmuseum.org/naukratis.

${ }^{11}$ It is likely that these figurines constituted for the most part the erotic group - though only males were referred to - found stuffed in drawers by Nicholas Warner and Theo Gayer- 


\section{Graeco-Roman Fertility Figurines from Gayer-Anderson Museum, Cairo}

were released few months ago to be displayed in a small showcase at the "Birth Room" in the ground floor of the older house. This article deals with a small selection of such fertility figurines: one (GA 871) on display at the Birth Room and five stored in the closet wall. Each has specific significance and reveals a certain role in festivals or religious rites.

\section{Harpocrates (GA 871)}

The figurine (fig. I. a) represents Harpocrates with a round face and full chubby cheeks. His hair is of shoulder-length with slight waves. The head is surmounted by the characteristic headdress of the god, which is the two lotus buds. Such headdress is related to the identification of Harpocrates in the Ptolemaic and Roman Periods with the new-born Sun emerging from the primeval ocean in the lotus chalice or on the lotus capsule. The legitimacy dogma raised by the Ptolemies had a significant impact on the iconography of Harpocrates as an heir of his father. ${ }^{13}$ The body is chubby and the legs are short. The god is shown asymmetrically squatting on a round base, with the left leg slightly raised and being apart from the right leaving the long penis exposed as the lower half of the figure is uncovered. He only wears a short sleeved tunic that is raised above the belly.

He holds a large globular jar under his left arm and his right hand is raised to his chin. Such pot is among the most common attributes of Harpocrates during that period. The scholars' opinions differed regarding its content being liquid, half solid, or solid. It recalls the shape of the traditional $n w$-jars that are used for water/ libation offerings; thus it could have the same function in this context being used for the offering of water or wine. ${ }^{14}$ It was hypothesized that it held Nile water, which was equated with Osiris by the ancient Egyptians ${ }^{15}$ and was known for its fertility, fructifying and regenerative powers. ${ }^{16}$ The god Horus, who became known as Harpocrates during the Graeco-Roman era, ${ }^{17}$ was involved in a certain ritual that is

Anderson, in which they were hidden since the time when the house was converted into a public museum. IKRAM, “A Pasha's Pleasures”, p. 183.

${ }_{12}$ Received date in the Museum Register is May 19, 1943. It was purchased for 1 EGP and 200 Milliemes, Records of Anderson Pasha, Vol. 1, p. 47, no. 23.

${ }^{13}$ L. Török, Hellenistic and Roman Terracottas from Egypt, Budapest, 1995, p. 57, 70.

${ }^{14}$ TÖRÖK, Hellenistic and Roman Terracottas from Egypt, p. 62-63.

${ }^{15}$ D. Delia, "The Refreshing Water of Osiris", JARCE 29, 1992, p. 182. , 184, 187.

16 P. GraIndOR, Terres Cuites de l'Égypte Grèco-romaine, Antwerpen, 1939, p. 85; E. O. JAMES, The Tree of Life. An Archaeological Study, Studies in the History of Religions 11, Leiden: E. J. Brill, 1966, p. 7.

${ }^{17}$ Plutarch identified Horus with Harpocrates when he stated the birth of Horus (PLUTARCH, Moralia V: Isis and Osiris, 19.358, 65. 377), see A. M. EL-KHACHAB, "Some Gem-Amulets 
purifying the Osirian King symbolizing resurrection and immortality. Another suggestion offered by Perdrizet claiming that the pot would contain thick porridge as a food for the baby upon weaning. ${ }^{18}$ Also, it had been proposed that it may have been linked with the preparation of a special food to be distributed to people, who would have been rather children, in honour of the god during a certain festival, i.e. Harpocrateia. ${ }^{19}$ The solid or half solid content can be better understood in view of the examples showing Harpocrates' hand being inserted inside the pot, thus eliminating the possibility that the content is liquid. ${ }^{20}$ Malaise assumes that the pot, held by Harpocrates, with which he assures a meal for his little followers, had the same function of the cornucopia. ${ }^{21}$

In the Pharaonic era, Harpocrates was putting his finger in the mouth as a sign of childhood; however the position of the fingers on the lips was characteristic to the Graeco-Roman Period. ${ }^{22}$ Plutarch interpreted this gesture as an indication of silence ${ }^{23}$ and other historians followed him such as Catullus and Ovid; but this was considered by some scholars as a misinterpretation, which continued up to the Renaissance period, since the ancient Egyptians depicted silence by placing the whole hand over the mouth. ${ }^{24}$

Depicting Harpocrates Seated on a Lotus Flower: To the Memory of My Great Friend Dr. Alexandre Piankoff", JEA 57, 1971, p. 132.

${ }^{18}$ P. PERDRIZET, Les terres cuites grecques d'Égypte de la collection Fouquet I, Nancy-ParisStrasbourg, 1921, p. XXI. He may have made this assumption through the story stated by Epiphanius, bishop of Salamis, who visited Egypt during the $4^{\text {th }}$ century AD; he described a festival related to Harpocrates at Buto, in which the adults are acting like children and smearing their faces with porridge and flour. F. WILliams (trans.), The Panarion of Epiphanius of Salamis. Books II and III. De Fide, Leiden, Boston: Brill University Press, 2013, p. 669.

${ }^{19}$ To give credibility for his suggestion, Frankfurter also provided an example of a recent tradition during the contemporary Festival of Buddha held in Japan, in which sweets are being distributed to children. D. FrANKFurTER, Religion in Roman Egypt. Assimilation and Resistance, Princeton: Princeton University Press, 1998, p. 54, 133.

${ }^{20}$ M. MALAISE, "Harpocrate au pot", in U. Verhoeven and E. Graefe (eds.), Religion und Philosophie im alten Àgypten, Festgabe fur Philippe Derchain, OLA 39, Leuven, 1991, p. 227.

${ }^{21}$ MALAISE, "Harpocrate au pot”, p. 231-232.

${ }^{22}$ EL-KHACHAB, "Some Gem-Amulets Depicting Harpocrates Seated on a Lotus Flower", p. 133 where the author also gives several interpretations for the finger in the mouth.

${ }^{23}$ Plutarch, Moralia V: Isis and Osiris, 68.378,

http://penelope.uchicago.edu/Thayer/E/Roman/Texts/Plutarch/Moralia/Isis_and_Osiris*/E. html.

24 R. B. WADDINGTON, "The Iconography of Silence and Chapman's Hercules", Journal of the Warburg and Courtauld Institutes 33, 1970, p. 256; EL-KHACHAB, "Some Gem-Amulets Depicting Harpocrates Seated on a Lotus Flower", p. 133-134; H. INGMAN, F. INGMAN, 


\section{Graeco-Roman Fertility Figurines from Gayer-Anderson Museum, Cairo}

The figurine is $14 \mathrm{~cm}$ in height, $9 \mathrm{~cm}$ in width, and $3 \mathrm{~cm}$ in depth. It is poorly modeled at the back with a circular vent (fig. I. b), hollowed from inside, and underside open (fig. I. c). It has a pink color traces all around that are quite evident in the grooves. There are white traces from inside.

\section{The so-called Baubo ${ }^{25}$ (GA 829) ${ }^{26}$}

The term "Baubo" refers to a type of female figurines shown in different aspects, of which the most common characteristics are chubby dwarf-like bodies, nakedness, crouching position, sagging breasts, exposing pudenda, and pointing to genitals. ${ }^{27}$ The name refers to the Greek goddess of Mirth who is associated with the myth of Demeter and Persephone. There were two versions in the ancient sources regarding the ritual performed to cure Demeter's depression because of her daughter's abduction by Hades, which made her laugh and break her fast. ${ }^{28}$ The first version is a decent jesting and jeering ritual made by Iambe, ${ }^{29}$ whereas the second involves the indecent exposure ritual made by Baubo through a kind of entertainment including dancing, lifting her skirt and exposing her body to the goddess. One version states that when pulling up her skirt, a boy's face was drawn on her abdomen; such surprising sight of the face replacing the sexual organs relieved the goddess from her grief. ${ }^{30}$

A similar excerpt is found in ancient Egyptian mythology written on Chester Beatty Papyrus dating to reign of Ramesses V and is currently kept at Chester Beatty Library in Dublin. In the story of the Contendings of Horus and Seth, when an obscure god called Babi rudely insulted the Tribunal of the gods, Re got furious and only laughed when Hathor exposed her private parts before

"Silence, Harpocrates and the "Cymbalum Mundi»", Bibliothèque d'Humanisme et Renaissance 51, no. 3, 1989, p. 572.

${ }^{25}$ Also, the term Pseudo-Baubo is sometimes used for this type of figurines since there is no consensus among the scholars as regards the character's identity. D. MiCHAELIDES, "Baubo and Priapos in Cyprus: A Note", Mediterranean Archaeology 17, Festschrift in Honour of J. Richard Green, 2004, p. 307.

${ }^{26}$ Received date in the Museum Register is May 17, 1943. It was purchased for 1 EGP, Records of Anderson Pasha, Vol. 1, p. 51, no. 53.

${ }^{27}$ MichaELIDES, "Baubo and Priapos in Cyprus: A Note", p. 307.

28 M. MARCOVICH, "Demeter, Baubo, Iacchus, and a Redactor", Vigiliae Christianae 40, no. 3 (Sep., 1986), p. 294.

${ }^{29}$ For the Iambe version tale, cf. H. G. EVELYN-WhITE (trans.), Hesiod: The Homeric Hymns and Homerica, London: W. Heinemann and New York: Putnam, 1920, p. 302-303 (Homeric Hymns to Demeter "lines 202-204").

${ }^{30}$ For the Baubo version tale, cf. Clement of Alexandria, Protrepticus II 20.1-21.1; A. H. Bryce, H. CAmpbell (trans.), The Seven Books of Arnobius Adversus Gentes, University of Edinburgh, 1871, p. 248-250 (Arnobius Adversus V. 25, 26). 
his eyes. ${ }^{31}$ Therefore, these figurines can be also called Hathoric figurines. ${ }^{32}$ This gesture was also attested in certain occasions in ancient Egypt as described by Greek historians. In the $5^{\text {th }}$ century BC, Herodotus stated that women in boats while going to Bastet's festival in Bubastis were lifting their garments and exposing their bodies. ${ }^{33}$ In the $1^{\text {st }}$ century $\mathrm{BC}$, there was a certain ritual made by women for forty days before the new selected bull replacing the dead Apis in Memphis, which involved pulling up their garments and exposing their bodies. ${ }^{34}$ Perhaps this gesture was regarded by both Greeks and Egyptians as an effective religious rite that would stimulate laughter in the case of upset deities. ${ }^{35}$

Also, there is a possibility that these figurines would have been used in rituals related to the Nile inundation. The Ramesside Papyrus Harris I mentions a tradition of throwing female wood figurines into the flooding Nile to arouse the desire of the god Hapy. ${ }^{36}$

Furthermore, such figurines were also interpreted as being women at the moment of delivery signifying fertility. Thus they could have meant to be used as amulets for protective purposes during childbirth. ${ }^{37}$

The figurine (fig. I. d) shows a sitting naked woman spreading her legs. She points with her right hand at the pubic area and rests the other hand on the left knee. An elaborate thick dotted headdress adorns the head over short irregular locks of hair above the forehead ending in long thin locks falling on the shoulders. She has large round breasts and swollen belly with exposed navel.

${ }^{31}$ Cf. A. H. Gardiner, The Library of A. Chester Beatty. Description of a Hieratic Papyrus with a Mythological Story, Love-Songs, and Other Miscellaneous Texts. The Chester Beatty Papyri, No. I, London: Oxford University Press, 1931, p. 16; W. K. SIMPSON (ed.), The Literature of Ancient Egypt. An Anthology of Stories, Instructions, Stelae, Autobiographies and Poetry, New Haven and London: Yale University Press, 2003, p. 94.

32 R. ThOMAs, "Egyptian Late Period figures in terracotta and limestone", in A. Villing, M. Bergeron, G. Bourogiannis, A. Johnston, F. Leclère, A. Masson, R. Thomas et al., Naucratis: Greeks in Egypt, p. 15, Online Research Catalogue of the British Museum. http://www.britishmuseum.org/naukratis.

${ }_{33} \mathrm{http} / / /$ penelope.uchicago.edu/Thayer/E/Roman/Texts/Herodotus/2A*.html: Herodotus II.60 (Loeb Classical Library).

${ }^{34} \mathrm{http}: / /$ penelope.uchicago.edu/Thayer/E/Roman/Texts/Diodorus_Siculus/1D*.html: Diodorus Siculus I.85 (Loeb Classical Library).

${ }^{35}$ A. NIFOSI, Becoming a Woman and Mother in Greco-Roman Egypt. Women's Bodies, Society and Domestic Space, London and New York: Routledge, 2019, p. 98.

${ }^{36}$ C. E. BARRETT, Egyptianizing Figurines from Delos. A Study in Hellenistic Religion, Columbia Studies in the Classical Tradition 36, 2011, p. 308-309.

37 M. Fueldhagen, Catalogue. Graeco-Roman Terracottas from Egypt. Ny Carlsberg Glyptotek, Copenhagen: Ny Carlsberg Glyptotek, 1995, p. 20. 


\section{Graeco-Roman Fertility Figurines from Gayer-Anderson Museum, Cairo}

The figurine is $10 \mathrm{~cm}$ in height, $10 \mathrm{~cm}$ in width, and $3.5 \mathrm{~cm}$ in depth. It is hollowed out from inside. The back is unmodelled with a circular vent (fig. I. e). The back part of the right foot is missing. The underside is not open. There is a small round hole at the top of the head, apparently for hanging purposes.

\section{Bes (GA 856) ${ }^{38}$}

This figure (fig. II. a) represents the god Bes shown as a warrior with the traditional grimacing look. The concept of such ugliness lies in his role as a preventative of evil spirits, which has the same function as the weapons often shown in his hands. ${ }^{39}$

He is dressed in a military costume wearing what appears to be short battle tunic with a cuirass, but not armed with the usual sword and shield. ${ }^{40}$ The military outfit and attributes, with which the god was always represented, could have been influenced by a Cretan myth related to the newborn Zeus when the Kouretes, being identified with the Daktyloi, managed to conceal the baby Zeus from the danger of his father, Cronos, by banging their swords against the shields whenever he cried. It was hypothesized that the weapons carried by Greek dwarfs are related to such myth, and thus could have been transferred to the Egyptian depiction of the dwarf Bes. ${ }^{41}$ Worthy of mention is that weapons (e.g. knife) were held by Bes in the Pharaonic era; the first attestation was in the New Kingdom under the reign of king Amenhotep III upon a bed footboard found in KV 46 showing Bes brandishing a knife with each hand. ${ }^{42}$

The head was surmounted by the characteristic headdress of the god that is the tall plumed crown, which is unfortunately broken and only its base is shown over the head. The dwarf is bending his right arm and resting the palm on his hip while he is carrying a pot with his left hand that is shown on his

\footnotetext{
${ }^{38}$ Received date in the Museum Register is May 18, 1943. It was purchased for 1 EGP and 300 Milliemes, Records of Anderson Pasha, Vol. 1, p. 46, no. 10.

${ }^{39}$ G. HART, The Routledge Dictionary of Egyptian Gods and Goddesses, London and New York: Routledge, 2005, p. 49.

${ }^{40}$ The Hellenistic form of the god Bes often shows him brandishing his sword, but with kind purposes, i.e. protecting the household and women in childbirth. M. GARMAISE, Studies in the Representations of Dwarfs in Hellenistic and Roman Art, PhD Thesis, McMaster University, 1996, p. 13.

${ }^{41}$ V. DASEN, Dwarfs in Ancient Egypt and Greece, Oxford, 1993, p. 204.

${ }^{42}$ J. F. Romano, The Bes-Image in Pharaonic Egypt, PhD Thesis, New York University, 1989, I, p. 66-67; II, 269-270 (cat. no. 86).
} 
shoulder. His legs are apart with a long phallus in between, which apparently gives a focus upon fertility and conception. Thus, within the same context, the pot or jug is more likely to be considered among the ritual accoutrements linked with Bes or a priest of Bes who could have been involved in certain obstetrical rite that may have served as an appeal to Bes through his likeness. ${ }^{43}$

The figurine is $11 \mathrm{~cm}$ in height, $8 \mathrm{~cm}$ in width, and $3 \mathrm{~cm}$ in depth. The back is unmodeled with an oval vent (fig. II. b). It is hollowed from inside, and underside is open (fig. II. c).

\section{Priapus (GA 818) ${ }^{44}$}

This figurine shows the Greek phallic god of fertility who was the son of Aphrodite. ${ }^{45}$ His father was most probably Dionysus. ${ }^{46}$ His origin and main cult center was in the Greek colony of Lampsacus (Lapseki in modern Turkey) on the Hellespont (modern Dardanelles). His cult extended to Greece following Alexander's death when ideas were conveyed between the East and West, and also reached great Hellenistic cities like Alexandria where his cult was very popular. ${ }^{47} \mathrm{He}$ was a guardian god of flocks and gardens. ${ }^{48} \mathrm{He}$ is characterized by his oversized erect phallus; such ithyphallic form would repel any evil forces that might be harmful to the crops, provide good luck, and keep away any danger, ${ }^{49}$ particularly thieves. The punishment can be easily speculated; it was sodomy with his large penis. ${ }^{50}$

\footnotetext{
${ }^{43}$ FrANKFURTER, Religion in Roman Egypt: Assimilation and Resistance, p. 127.

${ }^{44}$ Received date in the Museum Register is May 17, 1943. It was purchased for 1 EGP, Records of Anderson Pasha, Vol. 1, p. 51, no. 55.

${ }^{45}$ W. Smith, New Classical Dictionary of Greek and Roman Biography, Mythology and Geography, New York, 1878, p. 706.

${ }^{46}$ The identity of Priapus' father is not certain; however, most scholars refer to Dionysus, cf. C. Bostock, Debio Tibi Nihil: Priapus, Homosexuality, and Archetypal Psychology, PhD Dissertation, Pacifica Graduate Institute, USA, 2004, p. 58.

${ }^{47}$ M. CARy, J. D. Denniston, J. W. Duff, A. D. Nock, W. D. Ross, H. H. Scullare et al. (eds.), The Oxford Classical Dictionary, Oxford: Clarendon Press, 1949, p. 729. Worthy of mention is that there was a city in Asia Minor named after Priapus that was mentioned and described by classical writers as the "town of Priapos", i.e. Pliny (NH 5.38) and Strabo (VIII.I.12), cf. C. Moser, "Naked Power: The Phallus as an Apotropaic Symbol in the Images and Texts of Roman Italy", Undergraduate Humanities Forum 2005-6: Word \& Image 11, 2006, p. 27, http://repository.upenn.edu/uhf_2006/11.

${ }^{48}$ E. M. BERENS, The Myths and Legends of Ancient Greece and Rome, Amsterdam, 2009, p. 149.

49 A. Daniélou, The Phallus. Sacred Symbol of Male Creative Power, translated by J. Graham, Rochester, Vermont: Inner Traditions, 1995, p. 65.

${ }^{50}$ Bostock, Debio Tibi Nihil: Priapus, Homosexuality, and Archetypal Psychology, p. 57.
} 


\section{Graeco-Roman Fertility Figurines from Gayer-Anderson Museum, Cairo}

Out of the importance of this god in Egypt, his image was present in an Alexandrian procession together with those of Alexander and Ptolemy (Athen. 5.201D). ${ }^{51}$ Interestingly, in the writings of Diodorus Siculus (IV.6.3), he stated an ancient Egyptian myth related to Priapus' birth, in which the Titans slew Osiris and dismembered his body an threw his male organ into the river, then Isis traced his murder, overcame the Titans, and used the body pieces she found to shape Osiris figure with the exception of the penis which was not found, so she ordered the priests to give it the honours of a god and to be placed in the temples in an erect attitude. ${ }^{52}$ Thus the ancient Egyptians identified Priapus with Osiris' phallus. ${ }^{53}$

The figurine (fig. II. d) shows him standing over a base in between palm dates rising above the waist level. His head is surmounted by a calathus. He has a long oval beard and moustache. He is wearing a mantle. The right arm is folded over the chest and is slung in the drapery of the mantle, from which only the hand emerges. His mantle is raised up by the left hand showing the oversized phallus, which is restored.

The figurine is $15 \mathrm{~cm}$ in height, $8 \mathrm{~cm}$ in width, and $5 \mathrm{~cm}$ in depth. It is unmodelled at the back and hollowed out from inside, with the underside being open. There is a loop at nape for a carrying cord (fig. II. e).

\section{Pataikos (GA 904) ${ }^{54}$}

The figurine represents a grotesque Pataikos riding a phallus (fig. III. a). Ptah-Pataikos or Pataikos is an achondroplastic Memphite dwarf. ${ }^{55}$ The term Pataikos was first attested in Herodotus' writings about Cambyses' visit to Memphis; he described the images of Ptah, who was identified with Haephastus by the Greeks, in a form of dwarf. He stated that these images are similar to those of the Phoenician Pataïi/Pataikoi, which were carried on the prows of their boats; he added that these images were claimed to be the sons

\footnotetext{
${ }^{51}$ E. M. O'ConNor, Dominant Theme in Graeco-Roman Priapic Poetry, PhD Dissertation, University of California, Santa Barbara, 1984, p. 16.

${ }^{52}$ Diodorus Siculus (trans. By C. H. Oldfather), Diodorus of Sicily II, Books II.35- IV.58, Leob Classical Library no. 303, London: Harvard University Press, 1967, p. 359.

${ }^{53}$ NIFOSI, Becoming a Woman and Mother in Greco-Roman Egypt. Women's Bodies, Society and Domestic Space, p. 97.

${ }^{54}$ Received date in the Museum Register is May 25, 1943. It was purchased for 1 EGP, Records of Anderson Pasha, Vol. 1, p. 44, no. 89.

${ }^{55}$ C. E. BARRETt, Egyptianizing Figurines from Delos. A Study in Hellenistic Religion, Columbia Studies in the Classical Tradition 36, 2011, p. 260.
} 
of Haephastus/Ptah. ${ }^{56}$ Such new form of Ptah made its debut in the Late Period $;{ }^{57}$ however, Dasen stated a number of instances, in which it appeared only as small amuletic figurines since the New Kingdom. ${ }^{58}$ It had been suggested that this god is a manifestation of several major gods, which are the creator gods Ptah and Amun, the youthful gods Horus and Khonsu, the fertility god Min, as well as the forms of the night sun being Sokar and Osiris, thus merging their characteristics as young, creator and regenerator gods. $^{59}$

This figurine is better termed as Harpocratic-Pataikos since it combines Pataikos-like faces with Harpocrates' attribute(s) and/or gesture(s). ${ }^{60} \mathrm{He}$ is shown with his face grimacing with many wrinkles and furrowed forehead. The hair is covered by a hat ending at the top of the forehead with round band of combed hair framing the face above the ears, and is surmounted by two small lotus buds, which is the usual headdress of Harpocrates. Such contradiction between the wrinkled face and the attributes of the child god Harpocrates that are combined into an image of an aged infant can be interpreted as an embodiment of the "cosmic solar deity, who aged every night and was reborn in the morning" ${ }^{61}$ He wears a short draped tunic belted at the waist leaving the right shoulder and legs exposed. The head is turned to the right and leaning on the right shoulder providing a frontal view. The left hand having four fingers placed in the opened mouth while the thumb is on the left cheek; this gesture is similarly attested, but usually with the right hand, in a number of Harpocrates' figurines. ${ }^{62}$ The right hand is placed on the buttock.

${ }^{56}$ Herodotus III, 37, cf. A. D. GodLeY (trans.), Herodotus II. Books III and IV, London: William Heinemann, New York: G. P. Putnam's Sons, 1928, p. 49, 51.

${ }^{57}$ TÖRÖK, Hellenistic and Roman Terracottas from Egypt, p. 53.

58 DASEN, Dwarfs in ancient Egypt and Greece, p. 85.

59 DASEN, Dwarfs in ancient Egypt and Greece, p. 91. Barrett stated that in Egyptian religion, bringing together the features of several deities onto a single image makes that god to be regarded as "the henotheistic creator, the original god from whom all others emanate". C. E. BARrett, Diversity within Domestic Cult: A Contextual Analysis of Egyptianizing Terracotta Figurines from Delos, PhD Diss., Yale University, 2009, p. 399-400.

${ }^{60}$ BARRETT, Egyptianizing Figurines from Delos, p. 280-281.

${ }^{61}$ BARRETT, Diversity within Domestic Cult, p. 509.

${ }^{62}$ For examples, cf. J. FISCHER, Griechisch-Römische Terrakotten aus Ägypten. Die Sammlungen Sieglin und Schreiber: Dresden, Leipzig, Stuttgart, Tübingen, Tübinger Studien zur Archäologie und Kunstgeschichte 14, Berlin: Ernst Wasmuth Verlag, 1994, Nr. 582; TÖRÖK, Hellenistic and Roman Terracottas from Egypt, pl. XXXVIII (No. 60), XXXIX (No. 63); F. DunAND, Catalogues des terres cuites gréco-romaines d'Egypte, Paris, 1990, p. $67-68$, no. 119, 122. Also, the dwarfish figurines putting their hand in their mouth who had been described as "frères disgraciés d'Harpocrate, ou qui les représentent sous l'aspect misérable de grands maladies", also referred to as "Harpocrate Grotesque", see PERDRIZET, Les terres cuites grecques d'Égypte de la collection Fouquet I, p. 31, no. 93-94; II, pl. XXIII. 


\section{Graeco-Roman Fertility Figurines from Gayer-Anderson Museum, Cairo}

The most common related motif is a child-god (e.g. Harpocrates) riding animals, which has lots of Greek parallels; yet the figurines show a male riding phallus - or more specifically his own phallus - seems to be particularly Egyptian. ${ }^{63}$ Török stated that the phallophoria images and the phallic figures with Harpocrates' attributes are linked with both Bes and Harpocrates. The role of the god Bes seems to be helping to guide the phallus towards achieving its goal, i.e. reproduction. On the other hand, the figurines show Harpocrates riding the phallus-idol of Sokar, as an offspring and successor of his father, personifies the insurance of rebirth. Harpocrates was associated with Ptah-Sokaris-Osiris through the old relation between Horus and Sokar, and was represented in ithyphallic form through the identification of Horus with Min in the New Kingdom, thus the cult of Harpocrates was later introduced in the cult centers of the ithyphallic gods Min and Amun. ${ }^{64}$ Accordingly, riding the phallus ${ }^{65}$ could have been one of the rites performed by a cult attendant during the festival of Ptah-Pataikos in Memphis and was afterwards incorporated in the cult of Dionysus and his festival.

The figurine is $5 \mathrm{~cm}$ in height, $4.5 \mathrm{~cm}$ in width, and $1 \mathrm{~cm}$ in depth. No carving details are indicated at the back (fig. III. b). The figurine is not hollowed out and the base is not open. There are no holes whatsoever. There is a loop at the nape for a carrying cord.

\section{Symplegma (GA 860) ${ }^{66}$}

The terracotta shows copulating pair (fig. III. c). Both figures are standing with bent knees and represented half naked. The one to the front is shown with a hood revealing the front of curly/kinky hair round the childish face and is wearing a short tunic that is raised at the back. The back figure is shown with the curly hair partly covered with a veil and is wearing a short cloak with lots of drapes and is open from the front. The back figure puts the left hand over the right shoulder of the front figure while the right hand is holding the right waist.

Both figures seem to sit on a tree trunk or even riding a kind of animal since the front of the figurine shows what appears to be a third leg preceding the

\footnotetext{
${ }^{63}$ BARRETT, Diversity within Domestic Cult, p. 397, n. 325.

${ }^{64}$ TÖRÖK, Hellenistic and Roman Terracottas from Egypt, p. 52-53.

${ }^{65}$ Worthy of mention is that there is a Japanese Festival for Phallus Riding called Kanamara that is being held in the court of Wakamiya Hachimangu shrine in Yawata. Similarly, there is a Phallus Festival held every year in Greece in the city of Tyrnavos.

${ }^{66}$ Received date in the Museum Register is May 18, 1943. It was purchased for 2 EGP, Records of Anderson Pasha, Vol. 1, p. 46, no. 19.
} 
two legs of both figures. The front figure is resting his hands, the tips of which are broken, over that unidentified support. Both figures are turned with their faces to the right. They were sculpted from their right side while their left side (back of the figurine) is not carved (fig. III. d). The figurine measures $16 \mathrm{~cm}$ in height, $12 \mathrm{~cm}$ in width, and $3 \mathrm{~cm}$ in depth. It is fixed on a modern wooden base with a height of $4 \mathrm{~cm}$. The figure is heavy with no holes and not hollowed out from inside.

Symplegma scenes were represented in ancient Egypt, whether upon the walls of tombs, ostraca, papyri or through relief sculpture and statuary. ${ }^{67}$ It could have had certain significance since the ancient times related to the myth of Isis and Osiris. When Isis turned herself into a falcon to search for her husband, she found his body and placed herself on his erect phallus, thus conceiving Horus. Plutarch had explained this union stating that the Egyptians viewed Osiris as the efflux of the Nile, and Isis as the earth and the Nile is fructifying it and being united with it. ${ }^{68}$ So the copulating pair usually represents the union of Isis and Osiris reflecting the fertilization of Egypt by the Nile flood. This figurine shows the back adult as a female with the veil over the head, thus it would seem that both figures could have been involved in an acting ritual during a festival related to Nile inundation, in which the back figure acts as a female symbolizing that she is taking the active role. This can be simply interpreted through some of Isis hymns stating that she played the part of the man despite being a woman since Osiris was lifeless apart from his phallus. ${ }^{69}$

\section{General Commentary}

The Graeco-Roman Period in Egypt produced a large variety of small figurines mainly made of terracotta and a fewer quantity of other materials (e.g. limestone and faience) with various themes. The figurines included in this study are mainly related to domestic religious concerns of fertility, Nile inundation, as well as family health and protection. There was a general belief that the erotic figurines were produced out of Greek influence, however, it had been proved that such fertility themes had certain traditions

\footnotetext{
67 L. MANNICHE, Some Aspects of Ancient Egyptian Sexual Life, Leiden: Oostersch genootschap, 1977, p. 11-23.

68 J. G. GRIFFITH (ed. and trans.), Plutarch's De Iside et Osiride, University of Wales Press, 1970 , p. 38, 366a.

${ }^{69}$ M. J. Versluys, P. G. P. Meyboom, "The Meaning of Dwarfs in Nilotic Scenes", in L. Bricault, M. J. Versluys, P. G. P. Meyboom (eds.), Nile Into Tiber: Egypt in the Roman World, Proceedings of the IIIrd International Conference of Isis Studies, Faculty of Archaeology, Leiden University, May 11-14, 2005, Boston and Leiden: Brill, 2007, p. 189, 191.
} 


\section{Graeco-Roman Fertility Figurines from Gayer-Anderson Museum, Cairo}

in Egypt $^{70}$ with some exceptions, e.g. Priapus. The museum collection of the fertility figurines has no provenance, thus it would be very difficult to give an accurate dating.

The standard technique of the Graeco-Roman terracottas in Egypt mostly involved using two or three pieces of terracotta made by moulds. They were manufactured of dark reddish-brown Nile silt that was fired at a low temperature, thus producing hard, long-lasting and light figurine. It was then white washed and painted. The figurine is usually hollow, and sometimes with a circular or oval vent at the back. Such technique made its debut Egypt in the late $4^{\text {th }}$ century BC, presumably from Greece via Naucratis. The back was modelled in early Ptolemaic examples, yet the $3^{\text {rd }}$ and $2^{\text {nd }}$ century BC examples were mostly unmodelled. The Roman examples often missed the back vent. ${ }^{71}$ In many cases, the underside of the figurine is open.

The subjects of the museum fertility figurines were for the most part Egyptian deities (e.g. Harpocrates, Bes, and Pataikos), figurines related to Egyptian myths or rituals (e.g. Baubo and copulating pairs), as well as smaller group of Greek deities (e.g. Priapus) that only started to gain popularity in the $3^{\text {rd }}$ century $\mathrm{BC} .^{72}$

The god Harpocrates is the most popular divinity depicted in the GraecoEgyptian terracottas. He is always shown as chubby little boy sitting on the ground, standing or riding, whether clothed, naked or half naked, with curly hair or shaven head with the side lock, and mostly with the finger(s) touching his lips, and with the traditional headdress that is the double crown representing the royal authority over Upper and Lower flanked by two lotus buds, the latter feature is a new addition during the Graeco-Roman period. He is always shown with oversize phallus to emphasize the concept of fertility. His most common attributes being the cornucopia and the pot reflect the carrier as a bringer of every good thing, especially food and drink.

The naked females spreading their legs apart and pointing to the pubic area were generally regarded as symbols of fertility. Such figures were often called baubo as a referral to Eleusinian myth; however, it is strongly related to Egyptian myth and tradition, especially Hathor who is identified with Isis, the features or the attributes of both Egyptian goddesses appear on the figurines, especially the so-called Isis corkscrew curls. The hairstyle in many cases resembles that of the naked standing figures of Hathor with their hands

\footnotetext{
${ }^{70}$ THOMAS, "Egyptian Late Period figures in terracotta and limestone", p. 10.

${ }^{71}$ THOMAS, "Ptolemaic and Roman figures, models and coffin-fittings in terracotta", p. 3-5.

${ }^{72}$ THOMAs, "Ptolemaic and Roman figures, models and coffin-fittings in terracotta", p. 7.
} 
to the sides. ${ }^{73}$ Such Isis-Hathor aspect represents the figure as both mother and erotic being ${ }^{74}$ or simply as a mother during childbirth. These figurines always have either a hole at the top of the head, a small loop at the nape, or a bigger loop connecting the head with one arm (usually the right arm), which supports their usage as protective amulets.

Bes is among the very common figurines of the Graeco-Roman era, in which a change had been attested that is the military guise. He is always shown with the characteristic feathered crown, grimacing face, wearing a military costume, and holding shield and sword or sometimes a pot. The grimacing look of his face and the weapons held were to keep any danger away, thus reflecting protective features and attributes. The large phallus symbolizes fertility and the power to fend off evil. ${ }^{75}$ The pot attribute could have held material used during women's delivery - probably among certain rituals - in his role as protector of motherhood and childbirth. Worthy of mention is that the depiction of Bes upon the walls of the temples is different from the terracotta figurines indicating that the religious concern of the ordinary people is different from that of the priestly elite. ${ }^{76}$ The existence of such figurines shows a continuation of the domestic religion and its related practices in Egypt from the Late Period linked with family health and protection. ${ }^{77}$

Greek subject and style translated into small terracotta figurines were especially popular in Egypt in the $3^{\text {rd }}$ century BC. The figurines of Greek male deities were rare, among which is Priapus who had been one of the most popular gods together with Dionysus and Eros. ${ }^{78} \mathrm{He}$ is always shown as a bearded old man with a large erect phallus. Such fertility aspect, which would not only guarantee the abundance of the vegetation, but also keep

${ }^{73}$ D. M. BAILEY, Catalogue of the Terracottas in the British Museum IV. Ptolemaic and Roman Terracottas from Egypt, London, 2008, pl. I, p. 22-23 (no. 2991-2994).

${ }^{74}$ BAILEY, Catalogue of the Terracottas in the British Museum IV, p. 8.

${ }^{75}$ P. G. P. MeYboOm, M. J. Versluys, "The Meaning of Dwarfs in Nilotic Scenes", in L. Bricault, M. J. Versluys, P. G. P. Meyboom (eds.), Nile Into Tiber: Egypt in the Roman World, Proceedings of the IIIrd International Conference of Isis Studies, Faculty of Archaeology, Leiden University, May 11-14, 2005, Boston and Leiden: Brill, 2007, p. 176.

76 Y. VolOKHINE, "Bes dans les temples égyptiens de l'époque gréco-romaine", in L. Bricault and M. Versluys (eds.), Isis on the Nile. Egyptian Gods in Hellenistic and Roman Egypt, Proceedings of the IVth International Conference of Isis Studies, Liège, November 27-29, 2008, Religions in the Graeco-Roman World 171, Brill, Leiden, 2010, p. 233.

${ }^{77}$ R. THOMAS, "Ptolemaic and Roman figures, models and coffin-fittings in terracotta", in A. Villing, M. Bergeron, G. Bourogiannis, A. Johnston, F. Leclère, A. Masson, R. Thomas et al., Naucratis: Greeks in Egypt, p. 6. Online Research Catalogue of the British Museum. http://www.britishmuseum.org/naukratis.

78 THOMAS, "Ptolemaic and Roman figures", p. 7. 


\section{Graeco-Roman Fertility Figurines from Gayer-Anderson Museum, Cairo}

away the thieves and intruders from his territorial area, ${ }^{79}$ had provoked the ancient Egyptians farmers to include him within the domestic cult, ${ }^{80}$ especially that his birth had been related to an ancient Egyptian myth. The depictions of Priapus as ithyphallic bearded man with a calathus/modius and lifting his garment to expose his phallus were said to have come only from Roman Egypt; such erotic gesture of the god was protective and having the power to avert evil and bad luck. ${ }^{81}$

People were always fascinated by the physical appearance of the dwarfs, among which were the Pataikoi who suffered from Achonroplasia that is a disproportionate type where the forehead is enlarged and torso is normal with short limbs. ${ }^{82}$ Such type of dwarfs was linked with supernatural powers, which endowed them with protective traits. This conception may have been originated from their unfamiliar physical appearance that would strike horror and fear to the hearts of the viewers. ${ }^{83}$ Though Pataikos was first mentioned by Herodotus to indicate dwarf form of Ptah or sons of Ptah, it seems that he is not considered as a sole deity, but he was rather seen as manifestations of several gods. Since both infantile and mature features appear, in some cases, at the same time of the figure, then it is very likely that Pataikoi were linked with the continuing process of creation, i.e. the rising and setting sun, the newly born and the old, thus being connected with regeneration and fertility. These figurines were both protective and apotropaic; they guarded the family against any evil powers, particularly pregnant women who could have worn them during childbirth, as well as children. ${ }^{84}$ The figurine (GA 904) must have been used as an amulet since it is very light and has a small loop at the back.

Copulating pairs, in general, would have mostly shown a male and female, but apparently there were exceptions like GA 860 . They may have been used in certain rituals connected with fertility, e.g. Nile inundation. Only assumptions and no specific significance had been given for such figurines;

\footnotetext{
${ }^{79}$ Moser, "Naked Power", p. 36.

${ }^{80}$ BAILEY, Catalogue of the Terracottas in the British Museum IV, p. 95.

${ }^{81}$ NIFOSI, Becoming a Woman and Mother in Greco-Roman Egypt. Women's Bodies, Society and Domestic Space, p. 97.

${ }^{82}$ S. V. ERP, Pataikos. A Forgotten Amulet. A Study of the Pataikoi Amulets of the National Museum of Antiquities in Leiden, Master Thesis, Leiden University, 2014, p. 5.

83 R. ARAV and M. BERNETT, "An Egyptian Figurine of Pataikos at Bethsaida", Israel Exploration Journal 47, No. 3/4 1997, p. 205.

${ }^{84}$ V. DASEN, "Pataikos", in J. Eggler et Chr. Uehlinger (eds.), Iconography of Deities and Demons of the Biblical World (IDD), electronic prepublication, 2008, p. 4/6, see https://www.academia.edu/3816372/_Pataikos.
} 
however they could generally reflect the idea of rebirth and regeneration through sexual intercourse.

In general, such terracotta fertility figurines were very common in Egypt in the Graeco-Roman Period. These figurines could have been found in private houses for feeling relieved by their proximity, placed in temples for votive purposes, or included within the burials so as for the dead to guarantee rebirth. Some instances reflect a common religious tradition linking the Egyptians and the Greeks (e.g. Baubo and Priapus); the other Egyptian deities, however, were mostly fashioned in a Hellenized form. Thus both Egyptians and Greeks were acquiring such figurines for the same purposes. Their protective and apotropaic usage is quite obvious, yet they also may have been used in certain cultic rituals. It is also very likely that these figurines were mass-produced for festivals. Most important is the festival, which has been celebrated in Egypt on the occasion of the return of IsisHathor and her union with Osiris and the consequent birth of Harpocrates. The goddess' return was indicated by the rising of the Sothis (Sopdet) and thus marking the New Year, and was believed to stimulate the Nile inundation. The celebration is called the "Festival of Drunkenness" that was featured by dancing, singing, music, and alcoholic drinking. Terracotta figurines linked with fertility and Nile inundation were certainly included in such festivities, particularly Harpocrates, Bes, Pataikos, Baubo/Hathoric figurines, Priapus, and the act of cultic sex (hieros gamos). ${ }^{85}$

${ }^{85}$ THOMAS, "Egyptian Late Period figures in terracotta and limestone", p. 62. 
Graeco-Roman Fertility Figurines from Gayer-Anderson Museum, Cairo

\section{Plate I}

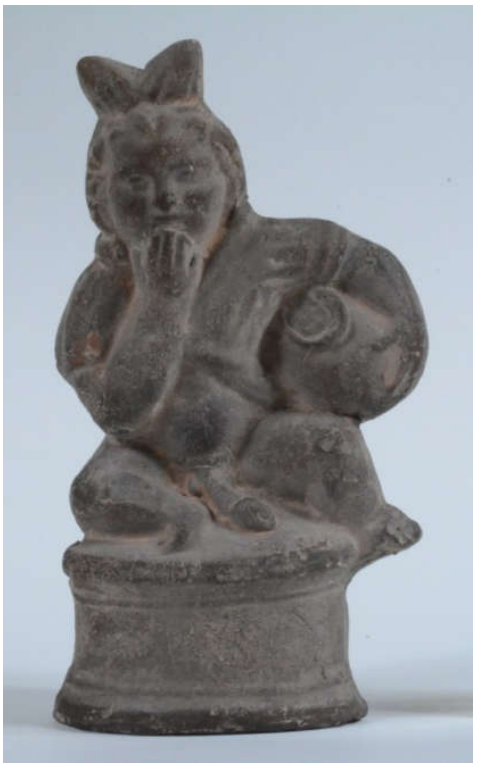

Fig. (a)

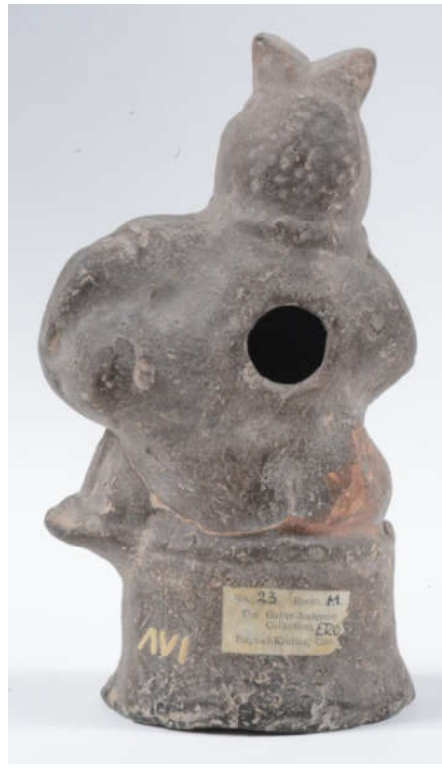

Fig. (b)

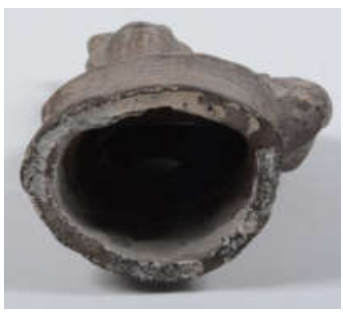

Fig. (c)

Harpocrates (GA 871)

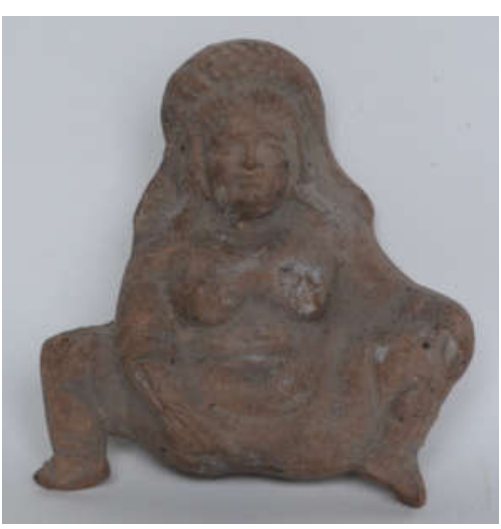

Fig. (d)

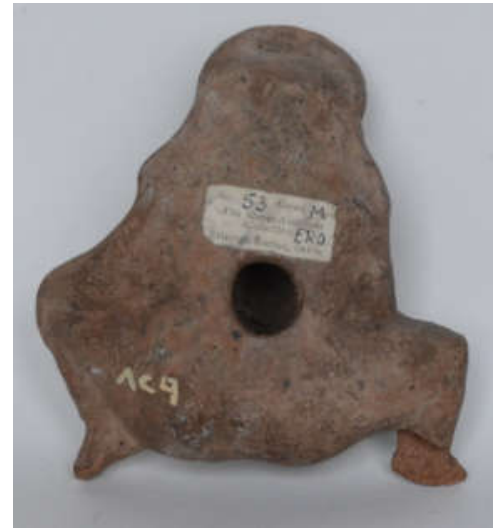

Fig. (e)

So-called Baubo (GA 829)

(C) Sameh Abdel-Mohsen 


\section{Plate II}

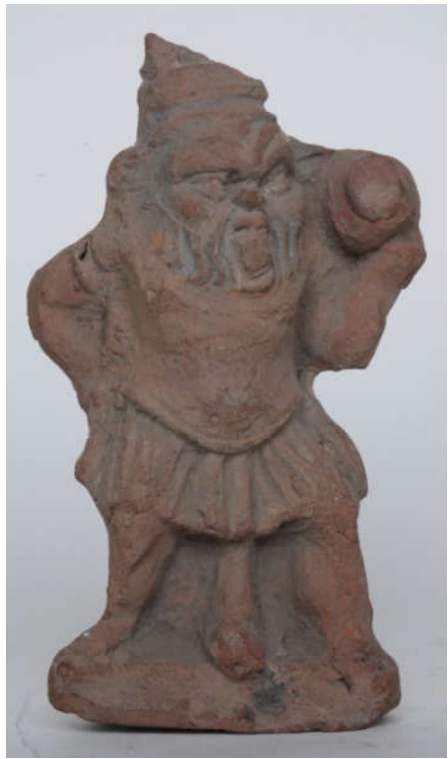

Fig. (a)

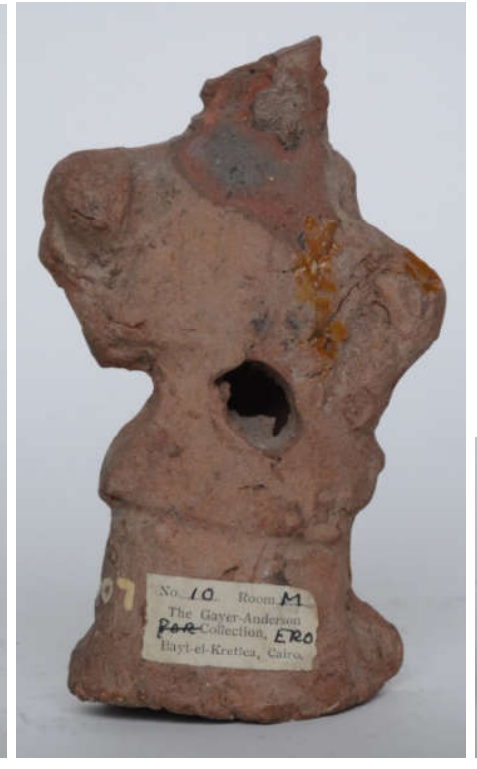

Fig. (b) Bes (GA 856)

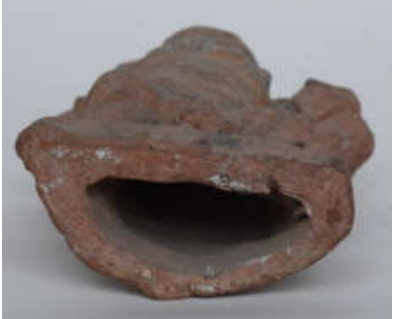

Fig. (c)

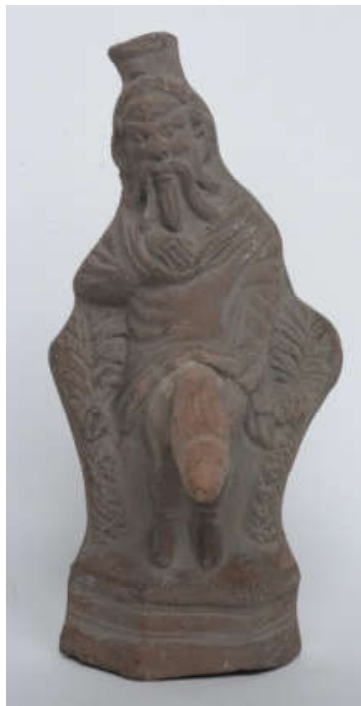

Fig. (d)

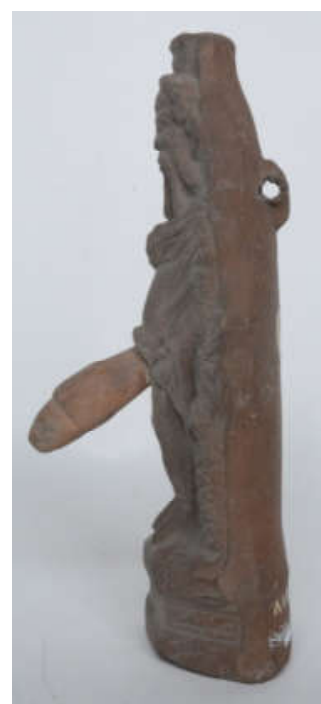

Fig. (e)

Priapus (GA 818)

(C) Sameh Abdel-Mohsen 
Graeco-Roman Fertility Figurines from Gayer-Anderson Museum, Cairo

\section{Plate III}
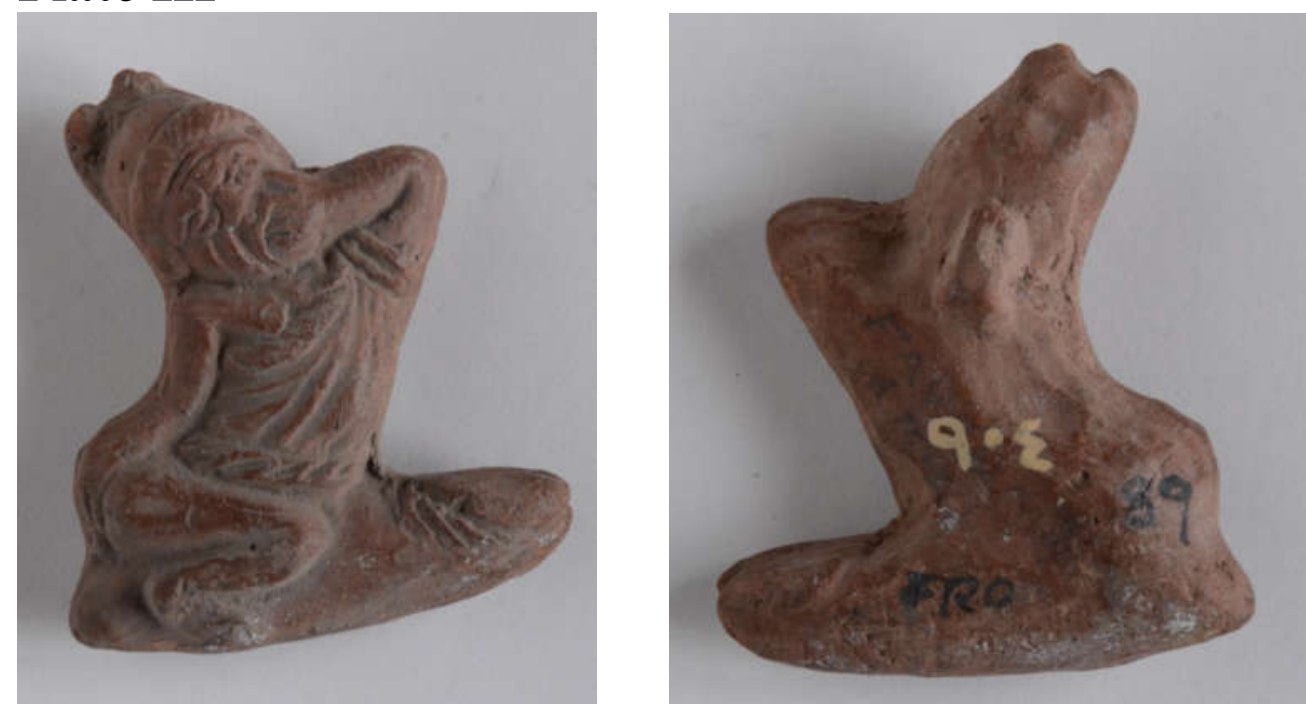

Fig. (a)

\section{Pataikos (GA 904)}

Fig. (b)

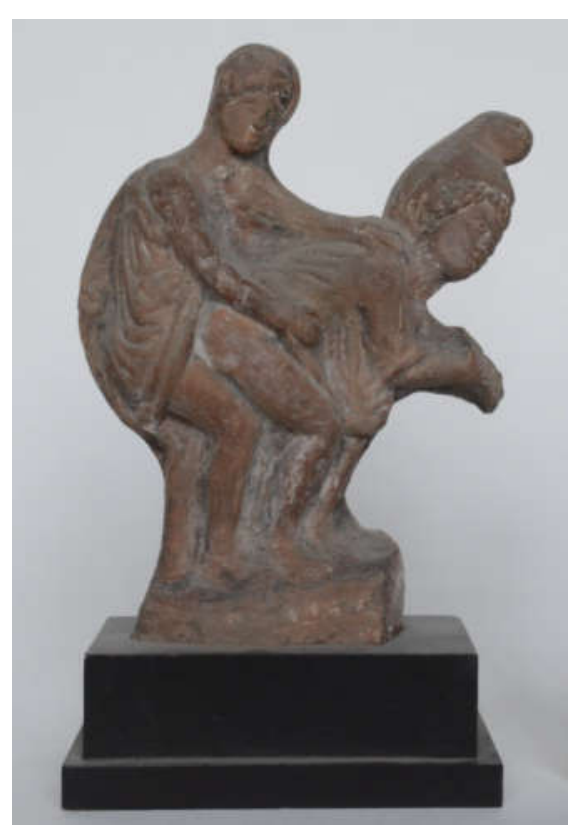

Fig. (c)

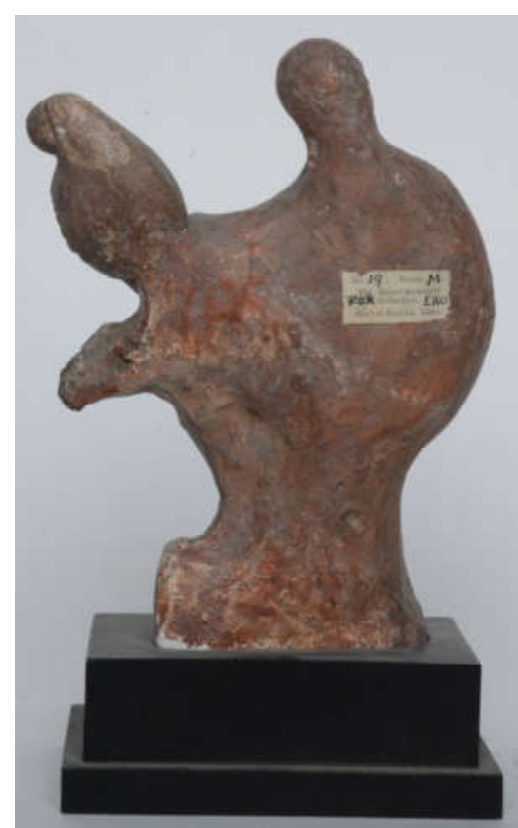

Fig. (d)

Symplegma (GA 860)

(C) Sameh Abdel-Mohsen 


\section{Bibliography}

- Abdel Salam, M. M. N., Derāṣa Tahlīliya lel-'Emāra Al-Dāhliya wa AlAțāt le-Beit Al-Kretliya wa-Ta'țìroh 'ala Al-Tașmìm Al-Dāhli wa Al-Ațāt fi El-Modon Al-Gadīda, unpublished M.Sc. Thesis, Helwan University, Cairo, 2003.

- Ahmed, M., Dalīl Mougaz le-Aham Al-'Ațār Al-'Arabiya bel-Qāhera, Cairo: Al-Matba a Al-'Amīriya be-Boulāq, 1938.

- ARAV, R. and M. Bernett, "An Egyptian Figurine of Pataikos at Bethsaida", Israel Exploration Journal 47, No. 3/4 1997, p. 198-213.

- BAILEY, D. M., Catalogue of the Terracottas in the British Museum IV. Ptolemaic and Roman Terracottas from Egypt, London, 2008.

- BArrett, C. E., Diversity within Domestic Cult: A Contextual Analysis of Egyptianizing Terracotta Figurines from Delos, PhD Diss., Yale University, 2009.

- Barrett, C. E., Egyptianizing Figurines from Delos. A Study in Hellenistic Religion, Columbia Studies in the Classical Tradition 36, 2011.

- Berens, E. M., The Myths and Legends of Ancient Greece and Rome, Amsterdam, 2009.

- Bostock, C., Debio Tibi Nihil: Priapus, Homosexuality, and Archetypal Psychology, PhD Dissertation, Pacifica Graduate Institute, USA, 2004.

- BRYCE, A. H.; H. CAMPBell (trans.), The Seven Books of Arnobius Adversus Gentes, University of Edinburgh, 1871.

- CARY, M.; J. D. Denniston; J. W. DufF; A. D. Nock; W. D. Ross; H. H. Scullare et al. (eds.), The Oxford Classical Dictionary, Oxford: Clarendon Press, 1949.

- Clement of Alexandria, Protrepticus II 20.1-21.1.

- DaniÉlou, A., The Phallus. Sacred Symbol of Male Creative Power, translated by J. Graham, Rochester, Vermont: Inner Traditions, 1995.

- DASEn, V., Dwarfs in Ancient Egypt and Greece, Oxford, 1993.

- DASEN, V., "Pataikos", in J. Eggler et Chr. Uehlinger (eds.), Iconography of Deities and Demons of the Biblical World (IDD), electronic prepublication, 2008, https://www.academia.edu/3816372/_Pataikos.

- Delia, D., "The Refreshing Water of Osiris", JARCE 29, 1992, p. 181-190.

- Dunand, F., Catalogues des terres cuites gréco-romaines d'Egypte, Paris, 1990.

- El-Habashi, A. E. E., Athar to Monuments: The Intervention of the Comite de Conservation des Monuments de L'Art Arabe, PhD Diss., University of Pennsylvania, 2001.

- El-Khachab, A. M., "Some Gem-Amulets Depicting Harpocrates Seated on a Lotus Flower: To the Memory of My Great Friend Dr. Alexandre Piankoff", Journal of Egyptian Archaeology 57, 1971, p. 132-145. 


\section{Graeco-Roman Fertility Figurines from Gayer-Anderson Museum, Cairo}

- ERP, S. V., Pataikos. A Forgotten Amulet. A Study of the Pataikoi Amulets of the National Museum of Antiquities in Leiden, Master Thesis, Leiden University, 2014.

- Evelyn-White, H. G. (trans.), Hesiod: The Homeric Hymns and Homerica, London: W. Heinemann and New York: Putnam, 1920.

- FISCHER, J., Griechisch-Römische Terrakotten aus Ägypten. Die Sammlungen Sieglin und Schreiber: Dresden, Leipzig, Stuttgart, Tübingen, Tübinger Studien zur Archäologie und Kunstgeschichte 14, Berlin: Ernst Wasmuth Verlag, 1994.

- Fueldhagen, M., Catalogue. Graeco-Roman Terracottas from Egypt. Ny Carlsberg Glyptotek, Copenhagen: Ny Carlsberg Glyptotek, 1995.

- Frankfurter, D., Religion in Roman Egypt. Assimilation and Resistance, Princeton: Princeton University Press, 1998, p. 54, 133.

- Gardiner, A. H., The Library of A. Chester Beatty. Description of a Hieratic Papyrus with a Mythological Story, Love-Songs, and Other Miscellaneous Texts. The Chester Beatty Papyri, No. I, London: Oxford University Press, 1931.

- Garmaise, M., Studies in the Representations of Dwarfs in Hellenistic and Roman Art, PhD Thesis, McMaster University, 1996.

- GaYer-Anderson, R. G. et al., Legends of the House of the Cretan Woman, Cairo: American University Press, 2001.

- Godley, A. D. (trans.), Herodotus II. Books III and IV, London: William Heinemann, New York: G. P. Putnam's Sons, 1928.

- Graindor, P., Terres Cuites de l'Égypte Grèco-romaine, Antwerpen, 1939.

- Griffith, J. G. (ed. and trans.), Plutarch's De Iside et Osiride, University of Wales Press, 1970.

- Grove, J. E., The Collection and Reception of Sexual Antiquities in the Late Nineteenth and Early Twentieth Century, unpublished PhD Thesis, University of Exeter, 2013.

- HaRT, G., The Routledge Dictionary of Egyptian Gods and Goddesses, London and New York: Routledge, 2005.

- Herodotus, Book III, Chapter 37.

- http://penelope.uchicago.edu/Thayer/E/Roman/Texts/Diodorus_Siculus/1D*. html: Diodorus Siculus I.85 (Loeb Classical Library).

- http://penelope.uchicago.edu/Thayer/E/Roman/Texts/Herodotus/2A*.html: Herodotus II.60 (Loeb Classical Library).

- IKrAM, S., "A Pasha's Pleasures: R.G. Gayer-Anderson and his Pharaonic Collection in Cairo", in S. D'Auria (ed.), Offerings to the Discerning Eye. An Egyptological Medley in Honor of Jack A. Josephson, Leiden, 2010, p. 177185. 
- Ingman, H.; F. Ingman, "Silence, Harpocrates and the «Cymbalum Mundi»”, Bibliothèque d'Humanisme et Renaissance 51, no. 3, 1989, p. 569577.

- James, E. O., The Tree of Life. An Archaeological Study, Studies in the History of Religions 11, Leiden: E. J. Brill, 1966.

- MAlaise, M., "Harpocrate au pot", in U. Verhoeven and E. Graefe (eds.), Religion und Philosophie im alten Àgypten, Festgabe fur Philippe Derchain, OLA 39, Leuven, 1991, p. 219-232.

- Manniche, L., Some Aspects of Ancient Egyptian Sexual Life, Leiden: Oostersch genootschap, 1977.

- Marcovich, M., "Demeter, Baubo, Iacchus, and a Redactor", Vigiliae Christianae 40, no. 3 (Sep., 1986), p. 294-301

- Meyboom, P. G. P.; M. J. Versluys, "The Meaning of Dwarfs in Nilotic Scenes", in L. Bricault, M. J. Versluys, P. G. P. Meyboom (eds.), Nile Into Tiber: Egypt in the Roman World, Proceedings of the IIIrd International Conference of Isis Studies, Faculty of Archaeology, Leiden University, May 11-14, 2005, Boston and Leiden: Brill, 2007, p. 170-208.

- Michaelides, D., "Baubo and Priapos in Cyprus: A Note", Mediterranean Archaeology 17, Festschrift in Honour of J. Richard Green, 2004, p. 307-309.

- Moser, C., "Naked Power: The Phallus as an Apotropaic Symbol in the Images and Texts of Roman Italy", Undergraduate Humanities Forum 20056: Word \& Image 11, 2006, http://repository.upenn.edu/uhf_2006/11.

- Mūḥammed, R. M., Madhal īlā Fan Al-Matāḥef, Cairo: Al-Dār Al-Māsrīā Allībnānnīā, 2002.

- Nifosi, A., Becoming a Woman and Mother in Greco-Roman Egypt. Women's Bodies, Society and Domestic Space, London and New York: Routledge, 2019.

- O'Connor, E. M., Dominant Theme in Graeco-Roman Priapic Poetry, PhD Dissertation, University of California, Santa Barbara, 1984.

- Perdrizet, P., Les terres cuites grecques d'Égypte de la collection Fouquet, Vol. I-II, Nancy-Paris- Strasbourg, 1921.

- Plutarch, Moralia V: Isis and Osiris, 68.378, http://penelope.uchicago.edu/Thayer/E/Roman/Texts/Plutarch/Moralia/Isis_ and Osiris*/E.html.

- Romano, J. F., The Bes-Image in Pharaonic Egypt, Vols. I-II, PhD Thesis, New York University, 1989.

- Siculus, Diodorus (translated by C. H. Oldfather), Diodorus of Sicily II, Books II.35- IV.58, Leob Classical Library no. 303, London: Harvard University Press, 1967.

- Simpson, W. K. (ed.), The Literature of Ancient Egypt. An Anthology of Stories, Instructions, Stelae, Autobiographies and Poetry, New Haven and London: Yale University Press, 2003. 


\section{Graeco-Roman Fertility Figurines from Gayer-Anderson Museum, Cairo}

- Smith, W., New Classical Dictionary of Greek and Roman Biography, Mythology and Geography, New York, 1878.

- Thomas, R. , "Egyptian Late Period figures in terracotta and limestone", in A. Villing, M. Bergeron, G. Bourogiannis, A. Johnston, F. Leclère, A. Masson, R. Thomas et al., Naucratis: Greeks in Egypt, Online Research Catalogue of the British Museum. http://www.britishmuseum.org/naukratis.

- ThOmas, R., "Ptolemaic and Roman figures, models and coffin-fittings in terracotta", in A. Villing, M. Bergeron, G. Bourogiannis, A. Johnston, F. Leclère, A. Masson, R. Thomas et al., Naucratis: Greeks in Egypt. Online Research Catalogue of the British Museum. http://www.britishmuseum.org/naukratis.

- Török, L., Hellenistic and Roman Terracottas from Egypt, Budapest, 1995.

- LOKHINE, Y., "Bes dans les temples égyptiens de l'époque gréco-romaine", in L. Bricault and M. Versluys (eds.), Isis on the Nile. Egyptian Gods in Hellenistic and Roman Egypt, Proceedings of the IVth International Conference of Isis Studies, Liège, November 27-29, 2008, Religions in the Graeco-Roman World 171, Brill, Leiden, 2010, p. 233-255.

- WAdDINGTON, R. B., "The Iconography of Silence and Chapman's Hercules", Journal of the Warburg and Courtauld Institutes 33, 1970, p. 248-263.

- Warner, N., Guide to the Gayer-Anderson Museum. Cairo, Cairo, 2003.

- WARner, N., Collecting for Eternity: R.G. Gayer-Anderson and the Egyptian Museum in Stockholm, Stockholm: National Museum of World Culture, 2016.

- Williams, F. (trans.), The Panarion of Epiphanius of Salamis. Books II and III. De Fide, Leiden, Boston: Brill University Press, 2013.

- Zaki, 'Abd Al-Raḥmān, Dor Al-Tohaf fi Misr we Al-Gam yāt Al-'Elmeya, Cairo, 1949.

- Zaki, 'Abd Al-Raḥmān, Mawso'at Madinat Al-Qāhīra fi Alf 'am, Cairo: Maktabat Al-Anglo Al-Masriah, 1969. 


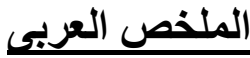 \\ تماثيل الخصوبة اليوناتية الرومانية من متحف جاير أندرسون، القاهرة نهى شلبي}

يشتمل متحف جاير أندرسون على عدد كبير من تماثيل الخصوبة، ولكن للأسف أغلبها غير

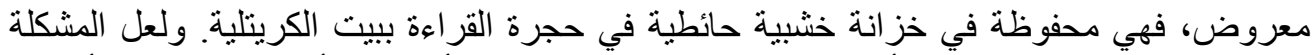

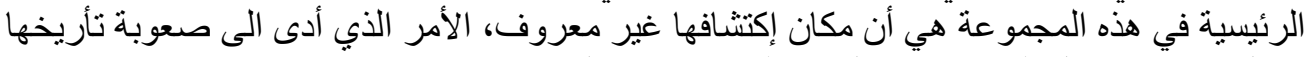
بشكل دقيق. وتماثيل الخصوبة بشكل عام لهان التاريخ طويل في مصر.

ولقد وقع الإختبار على ستة من هذه التماثيل، فقط إحداهم تم عرضه من شهور قليلة في حجرة الو لادة

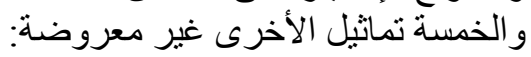
- ـثلاثة آلهة مصرية (حربوقر اطن، بس، باتايكوس) ولقد تم تمثيلهم بشكل إغريقى.

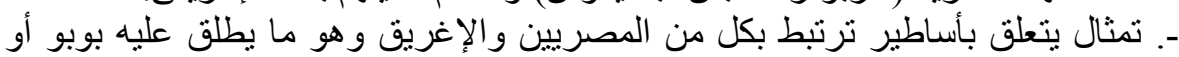

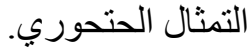

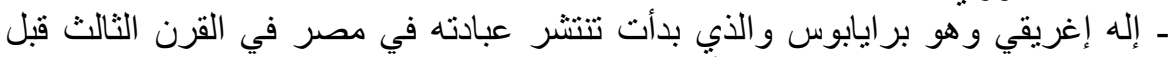

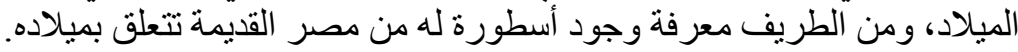

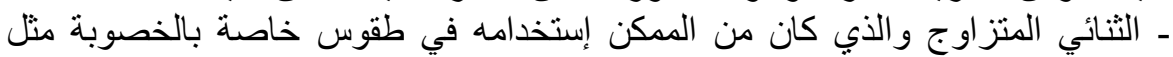

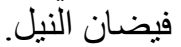

و التقنية الثائعة خلال العصر اليوناني الروماني لعمل أغلب هذه التماثثيل هي إستخدام قو الب لتشكيل

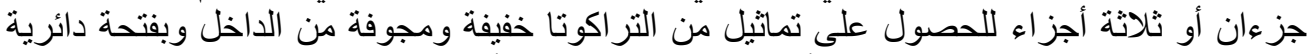

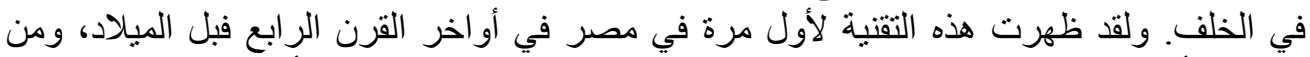

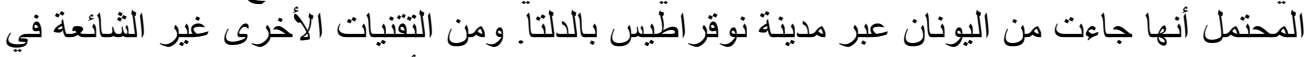

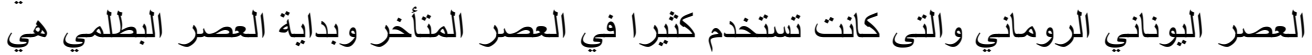

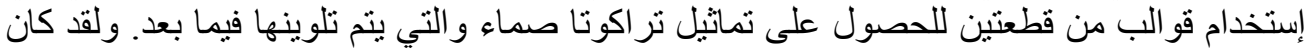

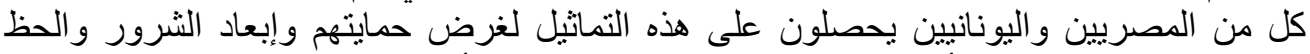

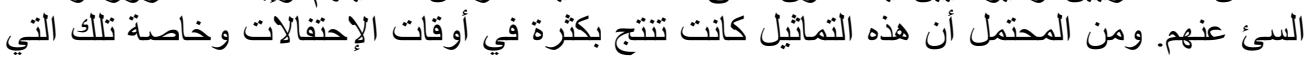

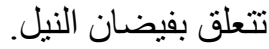

